\title{
Unmanned aerial vehicle for the assessment of woody and herbaceous phytomass in Sahelian savanna
}

\author{
Marina Bossoukpe ${ }^{1}$ Ousmane Ndiaye ${ }^{2}$ Ousmane Diatta ${ }^{2}$ \\ Sékouna Diatta ${ }^{1}$ Alain Audebert ${ }^{3,4}$ Pierre Couteron $^{5}$ \\ Louise Leroux ${ }^{6}$ Abdoul Aziz Diouf ${ }^{7}$ Morgane Dendoncker ${ }^{8}$ \\ Emile Faye $^{9,10}$ Simon Taugourdeau ${ }^{11}$
}

\section{Keywords}

Above ground biomass, trees, grasses, grassland management, multispectral imagery, Sahel, Senegal

(C) M. Bossoukpe et al., 202

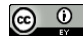

https://creativecommons.org/licenses/by/4.0/

Submitted: 10 December 2020

Accepted: 7 October 2021

Published: 20 December 2021

DOI: $10.19182 /$ remvt.36802

\begin{abstract}
Summary
The phytomass of herbaceous and woody plants is the main source of feed for pastoral livestock in the Sahelian savanna. The assessment of the available feedstock plays a key role in national livestock policies and generally requires many field measurements of both herbaceous and woody plants. In this study, we tested the possibility of using a red-green-blue (RGB) unmanned aerial vehicle (UAV) to evaluate the phytomass of both woody and herbaceous species. We thus mapped 38 one-hectare plots with a Dji Spark UAV in Northern Senegal. The herbaceous phytomass was measured on the ground. For the woody communities, we evaluated the leaf phytomass using dendrometric parameters combined with allometric equations. We performed partial-least-square regressions between UAV-based three-dimension and color indices and phytomass. Results showed a $\mathrm{Q}^{2}$ (cross-validation results for each response variable) of 0.57 for woody phytomass, 0.68 for herbaceous dry mass, and 0.76 for their fresh mass. This study confirmed the relevance of using low-cost RGB UAV to assess savanna phytomass.
\end{abstract}

- How to quote this article: Bossoukpe M., Ndiaye O., Diatta O., Diatta S., Audebert A., Couteron P., Leroux L., Diouf A.A., Dendoncker M., Faye E., Taugourdeau S., 2021. Unmanned aerial vehicle for the assessment of woody and herbaceous phytomass in Sahelian savanna. Rev. Elev. Med. Vet. Pays Trop., 74 (4): 199-205, doi: 10.19182/remvt.36802

\section{- INTRODUCTION}

The Sahel is an ecological transition zone between the Sahara to the north and the Sudanese savannas to the south. The climate is characterized by a long dry season (lasting from 9 to 11 months) followed by a short rainy season, with an increasing gradient in rainfall quantity

1. UCAD, Département de biologie végétale, PPZS, Dakar, Sénégal.

2. ISRA, CRZ Dahra-PPZS, Dahra Djoloff, Sénégal.

3. CIRAD, UMR AGAP, F-34398 Montpellier, France.

AGAP, Univ Montpellier, CIRAD, INRAE, Institut Agro, Montpellier, France.

4. ISRA, CERAAS, Thies, Sénégal.

5. CIRAD, UMR AMAP, F-34398 Montpellier, France.

AMAP, Univ Montpellier, CNRS, CIRAD, INRAE, IRD, Montpellier, France.

6. CIRAD, UPR AIDA, Dakar, Sénégal.

AIDA, Univ Montpellier, CIRAD, Montpellier, France.

7. Centre de suivi écologique, Fann Résidence, Dakar, Sénégal.

8. Université catholique de Louvain, Earth and Life Institute,

1348 Louvain-la-Neuve, Belgique.

9. CIRAD, UPR HortSys, F-34398 Montpellier, France.

HortSys, Univ Montpellier, CIRAD, Montpellier, France.

10. ISRA, CDH, Dakar 14000, Sénégal.

11. CIRAD UMR SELMET-PPZS, Dakar, Sénégal.

SELMET, Univ Montpellier, CIRAD, INRAE, Institut Agro, Montpellier, France. and in the length of the rainy season from north to south. Rainfall displays a high spatiotemporal variability (L'Hote et al., 2002).

Due to limited water availability, the vegetation in the Sahel belongs to the savanna type (Le Houerou, 1980) where herbaceous and woody communities coexist in a low woody cover. Annual herbaceous plants mostly grow during the rainy season. The main agricultural activity is transhumant pastoralism (Garba et al., 2012), which mainly depends on natural herbaceous and woody plants. Years with low rainfall can cause high mortality among the livestock (Lesnoff et al., 2012).

Because of the high climate variability and strong dependence of the local population on natural resources, the assessment of available resources (i.e. phytomass) is a key challenge for pastoralism and therefore for Sahelian countries' economy. Assessments are typically based on field measurements that are then scaled up using empirical statistical relationships applied to satellite imagery (Brandt et al., 2015). Field measurements are extremely time and labor consuming. Indeed, in the Sahel, larger areas need to be sampled (Levang and Grouzis, 1980) to cover the high heterogeneity of the herbaceous layer (Hiernaux et Gérard, 1999; Le Houerou, 1980; White, 1970). Moreover, woody and herbaceous species are usually assessed separately, thus preventing a global view of these ecosystems' state. 
The use of unmanned aerial vehicles (UAV) has considerably increased in recent years following lower prices, miniaturization, improved-sensor resolutions, and their easier use (piloting and flight programing) in particular to monitor vegetation across the world (Grenzdörffer et al., 2008). UAV have many advantages: they enable the production of very-high-resolution spatial images (less than $1 \mathrm{~cm}$ for red-green-blue [RGB] camera) at low cost with no weather constraints. Moreover, as images taken by UAV have sufficient overlap to a certain extent, the same object is photographed several times from slightly different angles and, thanks to a series of overlapping images, a three-dimensional (3D) model can be built by photogrammetry (Bossoukpe et al., 2021). From the 3D model, a digital surface model (DSM) and digital terrain model (DTM) can be computed to evaluate the height, the volume (based on the height) and the area of the object. This approach has already been used to measure the characteristics of trees in different types of ecosystems such as in orchards (Sarron, 2019), plantations (Anifantis et al., 2019), drylands (Cunliffe et al., 2016), tropical forests (Bourgoin et al., 2020) and natural savannas (Mayr et al., 2018).

Other tools than the UAV can be used to assess the woody and herbaceous phytomass. For instance, very-high-resolution-spatial (VHRS) images from satellites have been used to assess tree density (Brandt et al., 2020), and so has the tree-leaf area index (Taugourdeau et al., 2014). However, VHRS remote sensing tools have a lower spatial resolution than onboard UAV sensors. Furthermore, VHRS images are very costly and affected by cloudy conditions.

UAV sensors allow the computation of different VHRS RGB vegetation indices depending on the spectral specificity of onboard sensors. These indices can then be linked to different biophysical vegetation variables, particularly those of the herbaceous layer of crops or natural species. These indices can be combined with volumes obtained from the 3D model, then used to assess yield or biomass using multispectral mosaics for grassland (Pecina et al., 2021) or cropland (Roupsard et al., 2020). Some studies only used RGB indices (Lussem et al., 2019). UAV with RGB are widely available and much cheaper than multispectral UAV. It could be a relevant tool in developing countries where the funding of research institutes, agencies, and producer organizations are limited. Low-cost UAV could be very appropriate for these different users if they produce good enough results. In the Sahelian savannas both woody and herbaceous strata contribute to the available phytomass, i.e. the use of UAV is a possible way to monitor the two vegetation layers. The objective of the present study was thus to test the interest of using a UAV system with RGB images to estimate the phytomass of both herbaceous species and woody plants in Sahelian pastoral areas.

\section{MATERIALS ET METHODS}

The overall process of acquisition and data analysis are presented in Figure 1.

\section{Study area}

This study was conducted at the Center for Zootechnical Research (French abbreviation CRZ) of Dahra Djoloff in the sylvopastoral zone of Senegal, otherwise known as Ferlo. CRZ extends overs 6800 hectares that are managed by the Institut sénégalais de recherches agricoles (ISRA) (Raynal, 1964). Mean annual rainfall over the last 50 years was $371.6 \mathrm{~mm}$ (Fall, 2014). The soils are mainly sandy. We studied the vegetation on 38 one-hectare sites. The plots were chosen based on several vegetation dynamics (Raynal, 1964). Two types of data were acquired: (i) images with Dji Spark UAV and (ii) data for the phytomass collected in the field. All plots were georeferenced.

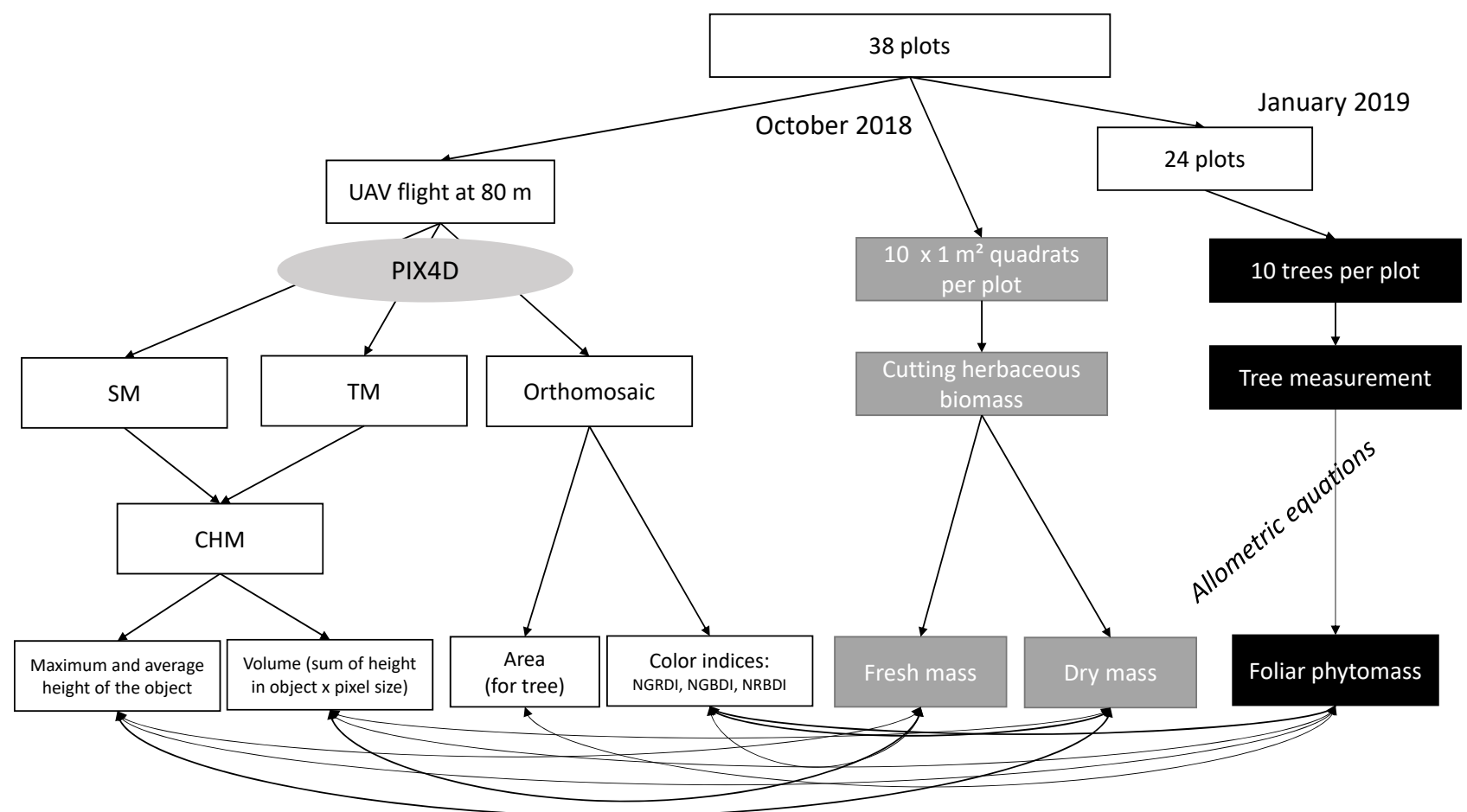

Figure 1: Graphic representation of the methodology used to assess grass and foliar phytomass with UAV in Sahelian savanna; SM: surface model; TM: terrain model; CHM: canopy height model; NRBDI = normalized difference between red and blue canals (Red-Blue) / (Red Blue); NGRDI = between red and green canals (Red-Green) / (Red Green); NGBDI = between green and blue canals (Green-Blue) / (Green Blue) /// Representation graphique de la méthodologie utilisée pour évaluer avec un drone la phytomasse herbacée et foliaire dans la savane sahélienne ; SM : modèle de surface ; TM : modèle de terrain ; $C H M$ : modèle de hauteur de canopée ; NRBDI = différence normalisée entre les canaux rouges et bleus (Red-Blue) / (Red Blue); NGRDI = entre les canaux rouges et verts (Red-Green) / (Red Green) ; NGBDI = entre les canaux verts et bleus (Green-Blue) / (Green Blue) 


\section{Images acquired with DJI Spark}

We used a Da-Jiang-Innovation (DJI) model Spark UAV. This very light drone has an integrated $12 \mathrm{M}$ pixels RGB camera in the visible band. The focus was set in automatic mode for all the shots. Images were acquired in jpeg format and geotagged using Spark-embedded global-positioning system (GPS). UAV was piloted from an android tablet. We used Litchi application to build the flight plans (https:// flylitchi.com/).

For each plot, one flight with six transects of $100 \mathrm{~m}$ separated by $20 \mathrm{~m}$ was performed at $80 \mathrm{~m}$ altitude and $5 \mathrm{~m} \cdot \mathrm{s}^{-1}$ speed. Images were acquired in autofocus mode (ISO exposure was automatically adjusted) at two-second intervals throughout the flight. We did not make any calibration. A color reference was put on the ground but the use of this reference induced poorer results (results not shown). We first tested the flight protocol with no calibration to see if a very simple protocol could be used. The angle of view was $80^{\circ}$. The frontal overlap was about $90 \%$ and the side one about $80 \%$. The flights were performed from October 1 to 15, 2018, in any light and weather conditions (at the end of the rainy season).

\section{Field measurements}

On each of the 38 one-hectare plots, we randomly selected ten onemeter-square quadrats. Next to each quadrat, a trash bag in the shape of an arrow was placed on the ground to enable us to identify correctly the quadrats on the images. All the flights took place before field measurements. Herbaceous vegetation in each quadrat was sampled in October 2018. The herbaceous phytomass was collected by cutting the grasses at ground level. The samples were directly weighed to obtain fresh phytomass (FM). A 300-g FM composite sample was made up for each plot (composite of the 10 quadrats). Each of the 38 composite samples was dried at $65^{\circ} \mathrm{C}$ until mass stabilization to measure the dry matter content (\%DM) of each plot. The same mean $\% \mathrm{DM}$ value was attributed to all the quadrats in one plot as it was impossible to dry all the samples.

Woody plants were measured in a subsample of 24 plots out of the 38 in January 2019 and January 2020. On each of the 24 plots, 10 adult trees ( $>1.3 \mathrm{~m}$ height; $>5 \mathrm{~cm}$ trunk diameter) were selected. The selection aimed to cover the diversity of the tree morphology present on the plot and was based on their height distribution from the canopy height model (CHM, see below) in order to have small, medium and tall woody individuals. Their GPS coordinates were obtained from the UAV outputs (see below). For each individual, the species was recorded and the diameter at $30 \mathrm{~cm}$ from ground level was measured. The diameter measurement at this height is recommended for the Sahel because of trees' morphology (Henry et al., 2011). A total of 239 woody individuals belonging to six species were recorded: Acacia nilotica $(\mathrm{n}=9)$, A. senegal $(\mathrm{n}=29)$, A. seyal Del $(\mathrm{n}=5)$, A. tortilis subsp. raddiana $(\mathrm{n}=54)$, Balanites aegyptiaca $(\mathrm{n}=132)$ and Boscia senegalensis $(\mathrm{n}=10)$. Allometric equations by Hiernaux (2006) were used to calculate the leaf dry phytomass based on the diameter. We did not have an equation for A. nilotica; given their similar morphology, that of $A$. tortilis was used in its stead.

\section{Image analysis}

The jpeg images acquired with UAV were processed with Pix4Dmapper software (www.pix4d.com). The automatic photogrammetric processing follows the structure from motion principles and comprises three main steps: initialization, densification, and model building. The initiation process detects and bundles the characteristic image objects (i.e. tie points) between overlapping parts of the geotagged images to create a sparse point cloud. In the densification step, the software looks for corresponding pixels and generates a densified point cloud thanks to a dense matching algorithm. Finally, by projecting UAV images on this cloud of points, the software generates orthorectified mosaics in tiff format. For each plot we used the basic settings ('3D map') of the software ${ }^{1}$ to generate an RGB orthomosaic, a digital surface model (DSM) and DTM in Universal-Transverse-Mercator coordinates system-zone $28 \mathrm{~N}$, datum WGS84. DSM is produced by the surface reconstruction method based on the point cloud. DTM is generated by using interpolating ground points based on the method by Becker et al. (2017). Some bare ground areas were present in some plots but we assumed that DTM was able to separate grass layer from soil.

The output rasters (orthomosaic, DSM, DTM) were exported to ArcGis to extract geometric data. Finally, the canopy height model was calculated as the difference between DSM and DTM. Figure 2 presents for one plot the four UAV outputs (mosaic, DSM, DTM and CHM). The orthomosaic and DSM had a ground sample distance (GSD) of $2.58 \mathrm{~cm}$. MNT and CHM had a GSD of $12.9 \mathrm{~cm}$, i.e. five times that of DSM.

To account for the diversity of tree heights in each plot, ten trees of different sizes were selected on the orthomosaic and the contour of their crowns was manually delineated. The one-meter-square quadrats were also delimited based on the presence of the markers (trash bags) on the ground.

The average and maximum CHM heights were extracted from all the quadrats and for all the selected trees (object). The volume was obtained by multiplying the sum of the heights of all pixels within an object by the unit area of the CHM raster pixel.

Colorimetric information (red, green and blue) was extracted for each tree or each herbaceous square. We directly used the digital number. We did not normalize the colors. Indeed, we did not have a ground reference that could have been used to correct the colors between plots. The only option would have been to normalize each plot separately but it would have created more differences between the different plots. Our goal was to test the relevance of using digital number directly in our indices. Subsequently, the normalized difference indices between the channels taken pairwise were calculated according to the following formula $(\mathrm{Cl}$ and $\mathrm{C} 2$ representing color 1 and color 2 , respectively).

$N C 1 C 2 D I=\frac{(C 1-C 2)}{(C 1+C 2)}$

Three indices were calculated: (i) normalized difference between the red and blue canals (NRBDI: [red-blue] / [red blue]); (ii) normalized difference between the red and green canals (NGRDI: [red-green] / [red green]); and (iii) normalized difference between the green and blue canals (NGBDI: [green-blue] / [green blue]). Lussem et al. (2018) found that NGRDI was an interesting index. The indices were calculated with the average colors of the object.

For the 10 trees per plot, the crown area was extracted from the orthomosaic and the ratio of this area to the maximum tree height was calculated. All UAV outputs and field measurements are available online (https://zenodo.org/record/5145395) (see Supplementary Materials for statistics on both tree and herbaceous subplots; UAV and phytomass).

\section{Data analysis}

Partial-least-square (PLS) regression (Tenenhaus, 1998) was used to predict woody and herbaceous phytomass with $\mathrm{R}$ plsdepot package (Sanchez, 2012). Herbaceous phytomass, fresh mass and dry mass were related with the PLS using the maximum height in the square (max), mean square height (mean), the height standard deviation

\footnotetext{
${ }^{1}$ https://support.pix4d.com/hc/en-us/articles/115002472186-Processing-steps
} 

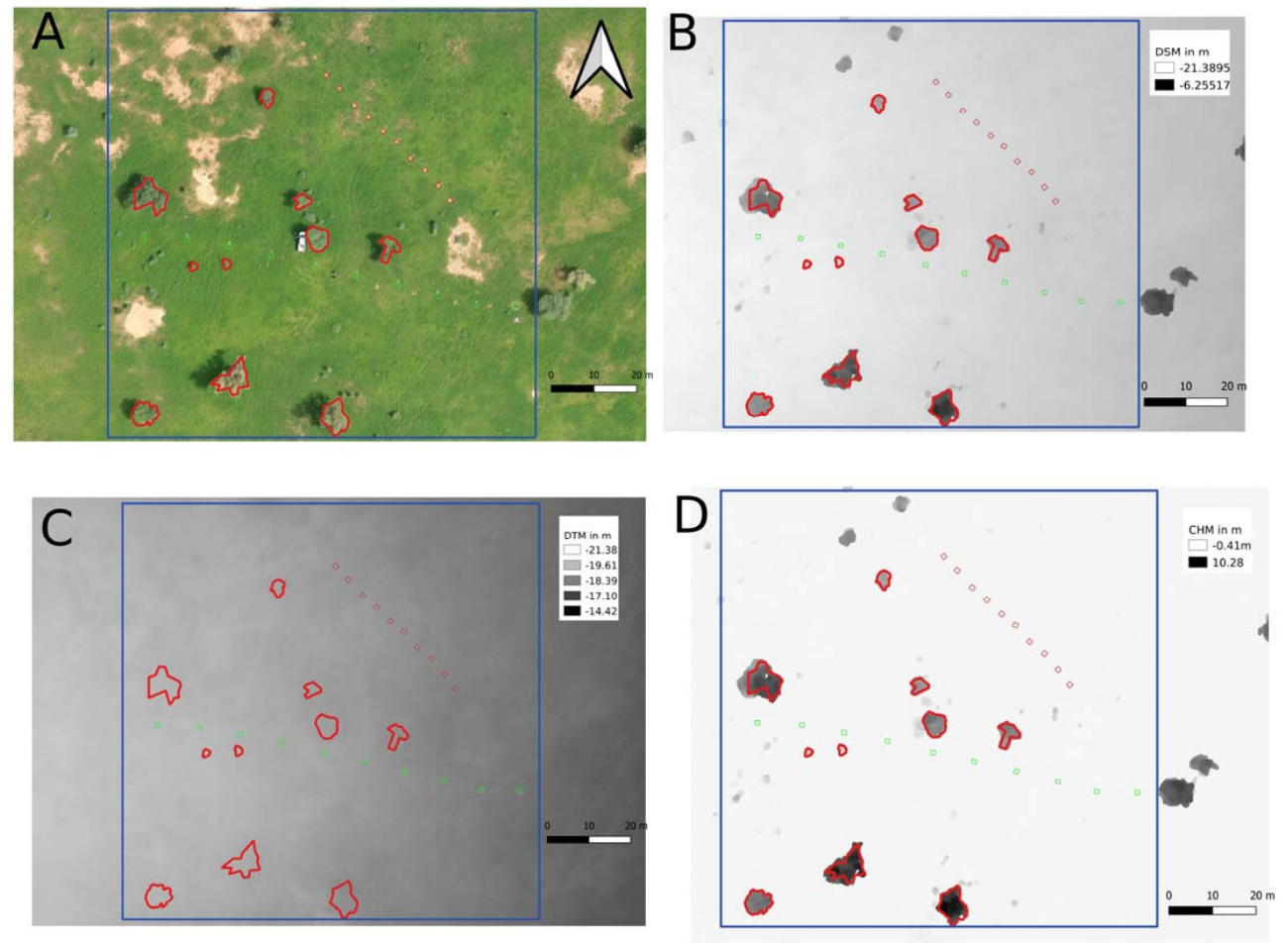

Figure 2: UAV outputs in Sahelian savanna. A) Orthomosaic with the position of the plot, the 10 selected trees and the $1-\mathrm{m}^{2}$ quadrats. B) DSM: digital surface model with the plot and the 10 selected trees. C) DTM: digital terrain model with the plot limits. D) CHM: canopy height model obtained by the difference between DSM and DTM /// Images obtenues par drone dans la savane sahélienne. A) Orthomosaïque avec la position de la parcelle, les 10 arbres sélectionnés et les quadrats de $1 \mathrm{~m}^{2}$. B) DSM : modèle numérique de surface avec la parcelle et les 10 arbres sélectionnés. C) DTM : modèle numérique de terrain avec les limites de la parcelle. D) CHM : modèle de hauteur de la canopée obtenu par la différence entre DSM et DTM.

within an object (tree and squares) (STD) obtained from CHM, volume (Vol) and the three normalized indices (NGRDI, NBGDI and NRBDI). Woody phytomasses from the allometric equations were related with the PLS from the previous variables along with the crown area (Area) and the ratio of the area to the maximum crown height $(\mathrm{AH}) . \mathrm{R}^{2}$ of the two axes were used to describe the explained variances of the two axes of the PLS. It corresponded to the correlation between the $\mathrm{Y}$ variables (here phytomass) and the axes of the PLS constructed with the UAV output variables. $Q^{2}$ represents the cross-validation results for each response variable (Sanchez, 2012). This value results of a cross validation and can be used to evaluate the predictive ability of the PLS regression.

\section{RESULTS}

\section{Woody phytomass}

Figure 3 shows the correlation circle obtained from the PLS regression made to predict the woody phytomass of trees obtained with the allometric equations. $\mathrm{R}^{2}$ (explained variance) was 0.59 for the first axis and 0.03 for the second. The biomass is mostly explained by the first axis of the PLS. The second axis was not important. The cumulative $\mathrm{Q}^{2}$ of the PLS was $0.57\left(\mathrm{Q}^{2}\right.$ of 0.57 for the first axis and 0.02 for the second). The woody phytomass was strongly correlated with the maximum height (max) and mean height of the trees (mean). The other structural indices (volume, standard deviation and area/ height ratio) were also linked with the woody phytomass but less correlated than height. The three color indices were not linked with the woody phytomass (see Suppl. Mat. for predicted vs observed phytomass).

\section{Herbaceous phytomass}

Figure 4 shows the correlation circle obtained from the PLS regression on dry and fresh matter phytomass (respectively DM and FM). $\mathrm{R}^{2}$ was 0.71 for the first axis and 0.02 for the second. $\mathrm{Q}^{2}$ for $\mathrm{DM}$ was 0.67 for the first axis and 0.02 for the second (cumulative $\mathrm{Q}^{2}=0.68$ ). $\mathrm{Q}^{2}$ for $\mathrm{FM}$ was 0.73 for the first axis and 0.09 for the second (cumulative $\mathrm{Q}^{2}=0.76$ ). Both masses were strongly correlated and linked with the two-color indices calculated with the green color: NBGDI and NGRDI (see Suppl. Mat. for predicted vs observed phytomass).

\section{DISCUSSION}

Our results showed that low-cost UAV can be used to evaluate efficiently the herbaceous phytomass and the woody leaf biomass. The percentage of variance explained by UAV outputs was around $60 \%$ for the woody leaf phytomass and 70\% for the herbaceous phytomass. The woody phytomass was mainly related to the $3 \mathrm{D}$ variables (area, height) and not to the color-based indices. Many studies have shown that UAV-based indices can be linked to the morphological features of trees (Surový et al., 2018). However, in our case, $41 \%$ of the variability of the woody phytomass was not explained by any UAV output. One part of the error observed could be due to the way we calculated the woody phytomass. We used allometric equations based on the trunk diameter. Collecting the woody phytomass (all the leaves of the tree) is laborious, so allometric equations with a few individuals are generally preferred and are not available for all species (Henry et al., 2011). Another source of imprecision could be due to the error from the allometric equation. 


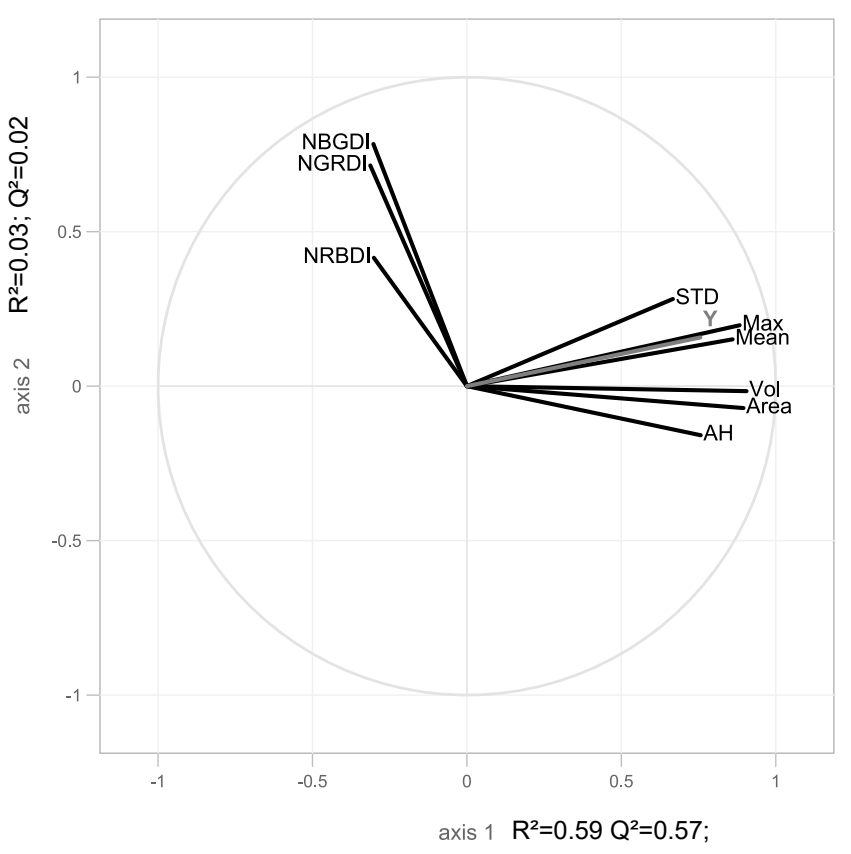

Figure 3: Partial-least-square regression between UAV variables and phytomass of the woody species $(\mathrm{Y})$. UAV variables are the maximum height (Max), mean height (Mean), standard deviation of the tree height (STD), projected volume ( $\mathrm{Vol}$ ), crown area (Area), ratio between maximum height and crown area $(\mathrm{AH})$, and three normalized vegetation indices: NRBDI, between red and blue canals (Red-Blue) / (Red Blue); NGRDI, between red and green canals (Red-Green) / (Red Green); NGBDI, between green and blue canals (Green-Blue) / (Green Blue). R2 explains variance of each axis /// Régression par moindres carrés partiels entre les variables obtenues par drone et la phytomasse des espèces ligneuses $(Y)$. Les variables drone sont la hauteur maximale (Max), la hauteur moyenne (Mean), l'écart-type de la hauteur des arbres (STD), le volume projeté (Vol), la superficie de la couronne (Area), le rapport entre la hauteur maximale et la superficie de la couronne $(A H)$, et trois indices de végétation normalisés : $N R B D I$, entre les canaux rouge et bleu (Red-Blue) / (Red Blue); NGRDI, entre les canaux rouge et vert (Red-Green) / (Red Green) ; NGBDI, entre les canaux vert et bleu (Green-Blue) / (Green Blue). $R^{2}$ explique la variance de chaque axe

An additional source of uncertainty could be the accuracy of the GPS positioning of the images. Indeed, Spark only records the geolocation at the second degree (around $10 \mathrm{~m}$ ) with no decimal point (contrary to other commonly used UAV for photogrammetry that have better geolocation accuracy). This limited geolocation capacity impacts the first step in PIX4D software. In the first step, the geolocation is corrected based on key points that are similar in different images. The geolocation of the image is the only referential that defines all the measurements that are used to define all the metrics in the 3D model so it can change. One way to correct the referential would be to position a 'reference' of known height, length and width (for example a car) in the plot. The most recent UAV such as DJI Mavic or Parrot Anafi have better geolocation accuracy. The problem is less important for herbaceous plants because they are mostly related to color based variables.

We did not correct the color reflectance between the different plots and the flights did not take place in exactly the same meteorological and sunlight conditions. That means that we did not use a color reference on the ground nor flew in normalized light conditions (i.e. flying only in homogenous cloudy conditions, or before sunrise or after sunset). We were not able to compare data with and without calibration but one part of the unexplained biomass variability could be explained by the differences in light conditions. Another possibility to improve the quality of the relationship would be to test some other vegetation indices based on RGB colors (Xue et $\mathrm{Su}$, 2017). In our

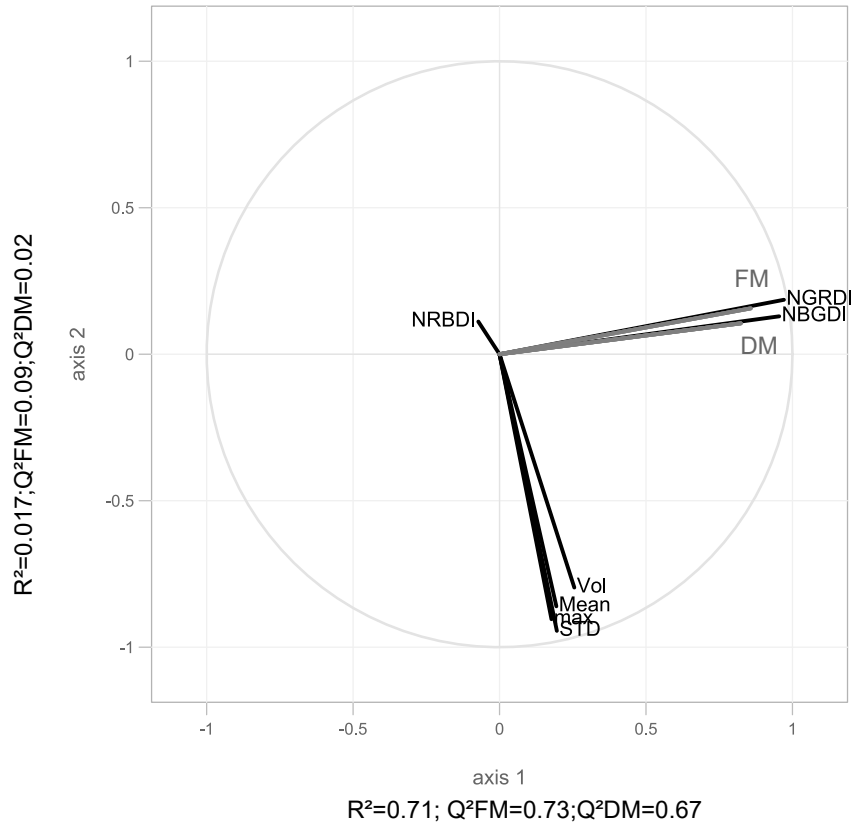

Figure 4: Partial-least-square regression between UAV variables and herbaceous phytomass: fresh phytomass (FM) and dry phytomass (DM). UAV variables are the maximum height (Max), average height (Mean), and standard deviation (STD) of the quadrats, volume of the quadrats $(\mathrm{Vol})$, and three normalized vegetation indices: NRBDI, between red and blue canals (Red-Blue) / (Red Blue); NGRDI, between red and green canals (Red-Green) / (Red Green); NGBDI, between green and blue canals (Green-Blue) / (Green Blue). R² explains variance of each axis. $\mathrm{Q}^{2}$ is obtained from the cross-validation process /// Régression par moindres carrés partiels entre les variables obtenues par drone et la phytomasse herbacée : phytomasse fraîche (FM) et sèche (DM). Les variables drone sont la hauteur maximale (Max), moyenne (Mean) et l'écart-type (STD) des quadrats, le volume des quadrats (Vol), et trois indices de végétation normalisés: NRBDI, entre les canaux rouge et bleu (Red-Blue) / (Red Blue); NGRDI, entre les canaux rouge et vert (Red-Green) / (Red Green) ; NGBDI, entre les canaux vert et bleu (Green-Blue) / (Green Blue). $R^{2}$ explique la variance de chaque axe. $Q^{2}$ est obtenu par processus de validation croisée

work, we only used visible colors. In many remote sensing studies, infrared is used to evaluate the vegetation biomass. We can assume that infrared could improve the quality of the prediction. Hyperspectral UAV could also capture the quality and not only the quantity of forage (Gao et al., 2019). However, multi- and hyper-spectral UAV are more expensive than visible UAV.

In our work the 3D indices based on photogrammetry were not related to herbaceous phytomass. In other studies (Lussem et al., 2019; Possoch et al., 2016), 3D indices were more relevant as predictors. These studies were mostly based on experimental designs that created more visible differences in plant heights. Furthermore, flight altitude was lower (around $20 \mathrm{~m}$ above ground). We chose a flight height of $80 \mathrm{~m}$ to obtain a good 3D representation of the woody layer (Sadeghi et Sohrabi, 2019). Indeed, in low flight height, the distance between the tree crown and the captor is too short, which can be problematic in the photogrammetry of woody individuals and sometime of the whole plot.

\section{CONCLUSION}

This study shows that it is possible to use low-cost UAV to predict woody and herbaceous phytomass in the savanna. For the woody phytomass, the estimation is mainly based on the 3D structure of the woody individuals. The link between UAV and tree structure is generic and not impacted by the UAV type. For herbaceous plants, 
we may assume that the relationships are less generic and have to be calibrated for each study. UAV can be used as an intermediate tool between field measurements and remote sensing images usually used for vegetation monitoring. UAV can produce a biomass map of several hectares considering the vegetation variability. The UAV map produced can be linked with remote sensing data. The use of UAV is one way to reduce the sampling effort in the field that is usually undertaken to monitor vegetation in this region. The very high resolution RGB mosaics are also useful to study spatial patterns of vegetation and particularly the impact of the woody cover on the herbaceous cover.

\section{Acknowledgments}

This research was financed by the Carbon Sequestration and Greenhouse Gas Emissions in (Agro) Sylvopastoral Ecosystems in the Sahelian CILSS States (CaSSECS) project, supported by the European Union under the Development Smart Innovation through Research in Agriculture (DeSIRA) Initiative. The opinions expressed in this article are not necessarily those of the European Union.

\section{Author contributions statement}

$\mathrm{MB}, \mathrm{ST}$ and EF carried out conceptualization, data curation and formal analysis. OD, ON and MD performed investigation. ST made the figures, wrote the original draft and obtained funding. MB, EF, OD, ST, MD, OD developed the methodology. MB, OD, ON, SD, AA, PC, $\mathrm{LL}, \mathrm{AAD}, \mathrm{MD}$, EF contributed to reviewing and editing.

\section{Conflicts of interest}

The authors declare no conflict of interest.

\section{REFERENCES}

Anifantis A.S., Camposeo S., Vivaldi G.A., Santoro F., Pascuzzi S., 2019. Comparison of UAV photogrammetry and 3D modeling techniques with other currently used methods for estimation of the tree row volume of a superhigh-density olive orchard. Agriculture 9 (11): 233, doi: 10.3390/agriculture911023

Becker C., Häni N., Rosinskaya E., d'Angelo E., Strecha C., 2017. Classification of aerial photogrammetric 3D point clouds. ISPRS Ann. Photogramm. Remote Sens. Spatial Inf. Sci., IV-1W/1: 3-10 doi: 10.5194/isprs-annals-IV1-W1-3-2017

Bourgoin C., Betbeder J., Couteron P., Blanc L., Dessard H., Oszwald J., Le Roux R., et al., 2020. UAV-based canopy textures assess changes in forest structure from long-term degradation. Ecol. Ind., 115: 106386, doi: 10.1016/j. ecolind.2020.106386

Brandt M., Mbow C., Diouf A.A., Verger A., Samimi C., Fensholt R., 2015. Ground- and satellite-based evidence of the biophysical mechanisms behind the greening Sahel. Global Change Biol., 21 (4): 1610-1620

Brandt M., Tucker C.J., Kariryaa A., Rasmussen K., Abel C., Small J., Chave J., et al., 2020. An unexpectedly large count of trees in the West African Sahara and Sahel. Nature, 587: 78-82, doi: 10.1038/s41586-020-2824-5

Cunliffe A.M., Brazier R.E., Anderson K., 2016. Ultra-fine grain landscape-scale quantification of dryland vegetation structure with drone-acquired structure-from-motion photogrammetry. Remote Sens. Environ., 183: 129-143, doi: 10.1016/j.rse.2016.05.019

Fall A., 2014. Approche géographique de la vulnérabilité des anthroposystèmes sahéliens. Thèse Doct., Sorbonne, Paris, France

Gao R., Kong Q., Wang H., Su Z., 2019. Diagnostic feed values of natural grasslands based on multispectral images acquired by small unmanned aerial vehicle. Rangel. Ecol. Manag., 72 (6): 916-922

Garba I., Cesaro J.-D., Touré I., Ickowicz A., Toutain B., 2012. Evolution des transhumances. In: Atlas des évolutions des systèmes pastoraux au Sahel : 1970-2012. FAO, Rome, Italie, p. 14-15

Grenzdörffer G., Engel A., Teichert B., 2008. The photogrammetric potentia of low-cost UAV in forestry and agriculture. Remote Sens. Spat. Inf. Sci., 31 (B3): 1207-1214
Henry M., Picard N., Trotta C., Manlay R., Valentini R., Bernoux M., Saint André L., 2011. Estimating tree biomass of subSaharan African forests: a review of available allometric equations. Silv. Fenn., 45 (3B): 477-569, doi: $10.14214 / \mathrm{sf} .38$

Hiernaux P., 2006. Le suivi écologique de Widou Thiengoly : un patrimoine scientifique à développer et valoriser. Rapport de mission, Saint-Louis, Sénégal, PAPF 47

Hiernaux P., Gérard B., 1999. The influence of vegetation pattern on the productivity, diversity and stability of vegetation: The case ofbrousse tigrée'in the Sahel. Acta oecologica, 20 (3): 147-158, doi: 10.1016/S1146609X(99)80028-9

L'Hote Y., Mahé G., Somé B., Triboulet J.P., 2002. Analysis of a Sahelian annual rainfall index from 1896 to 2000; the drought continues. Hydrol. Sci. J., 47 (4): 563-572, doi: 10.1080/02626660209492960

Le Houerou H.N., 1980. The rangelands of the Sahel. J. Range Manag., 33 (1): 41-46, doi: 10.2307/3898226

Lesnoff M., Corniaux C., Hiernaux P., 2012. Sensitivity analysis of the recovery dynamics of a cattle population following drought in the Sahel region. Ecol. Model., 232: 28-39, doi: 10.1016/j.ecolmodel.2012.02.018

Levang P., Grouzis M., 1980. Méthodes d'étude de la biomasse herbacée de formations sahéliennes: application à la Mare d'Oursi, Haute-Volta. Oecol. Plant., 1 (15): 231-244

Lussem U., Bolten A., Gnyp M., Jasper J., Bareth G., 2018. Evaluation of RGBbased vegetation indices from UAV imagery to estimate forage yield in grassland. Int. Arch. Photogramm. Remote Sens. Spatial Inf. Sci., 42 (3): 12151219, doi: 10.5194/isprs-archives-XLII-3-1215-2018

Lussem U., Bolten A., Menne J., Gnyp M.L., Schellberg J., Bareth G., 2019. Estimating biomass in temperate grassland with high resolution canopy surface models from UAV-based RGB images and vegetation indices. J. Appl. Remote Sens., 13 (3): 034525, doi: 10.1117/1.JRS.13.034525

Mayr M.J., Malß S., Ofner E., Samimi C., 2018. Disturbance feedbacks on the height of woody vegetation in a savannah: a multi-plot assessment using an unmanned aerial vehicle (UAV). Int. J. Remote Sens., 39 (14): 4761-4785, doi: 10.1080/01431161.2017.1362132

Pecina M.V., Bergamo T.F., Ward R., Joyce C., Sepp K., 2021. A novel UAVbased approach for biomass prediction and grassland structure assessment in coastal meadows. Ecol. Indic., 122: 107227

Possoch M., Bieker S., Hoffmeister D., Bolten A., Schellberg J., Bareth G., 2016. Multi-temporal crop surface models combined with the RGB vegetation index from UAV-based images for forage monitoring in grassland. Remote Sens. Spat. Inf. Sci., 41: 991, doi: 10.5194/isprsarchives-XLI-B1-991-2016

Raynal J., 1964. Etude botanique de pâturages du Centre de Recherches Zootechniques de Dahra-Djoloff (Sénégal). Orstom, Paris, France, 99 p.

Roupsard O., Audebert A., Ndour A.P., Clermont-Dauphin C., Agbohessou Y., Sanou J., Koala J., et al., 2020. How far does the tree affect the crop in agroforestry? New spatial analysis methods in a Faidherbia parkland. Agric. Ecosyst. Environ., 296: 106928, doi: 10.1016/j.agee.2020.106928

Sadeghi S., Sohrabi H., 2019. The effect of UAV flight altitude on the accuracy of individual tree height extraction in a broad-leaved forest. Remote Sens. Spat. Inf. Sci., 42 (4/W18), doi: 10.5194/isprs-archives-xlii-4-w18-1168-2019

Sanchez G., 2012. plsdepot: Partial Least Squares (PLS) Data Analysis Methods. R package version 0.1.17. https://CRAN.R-project.org/package=plsdepot

Sarron J., 2019. Estimation spatialisée des rendements d'une culture pérenne en Afrique de l'Ouest : le cas du manguier au Sénégal. SupAgro, Montpellier, France

Surový P., Almeida Ribeiro N., Panagiotidis D., 2018. Estimation of positions and heights from UAV-sensed imagery in tree plantations in agrosilvopastoral systems. Intern. J. Remote Sens., 39 (14): 4786-4800, doi: 10.1080/01431161.2018.1434329

Taugourdeau S., Le Maire G., Avelino J., Jones J.R., Ramirez L.G., Quesada M.J., Charbonnier F., et al., 2014. Leaf area index as an indicator of ecosystem services and management practices: an application for coffee agroforestry. Agric. Ecosyst. Environ., 192: 19-37, doi: https://doi.org/10.1016/j. agee.2014.03.042

Tenenhaus M., 1998. La régression PLS: théorie et pratique. Technip, Paris, France, $254 \mathrm{p}$.

White L., 1970. Brousse tigrée patterns in southern Niger. J. Ecol., 58 (2): 549 553, doi: 10.2307/2258290

Xue J., Su B., 2017. Significant remote sensing vegetation indices: A review of developments and applications. J. Sens., Article ID 1353691, 17 p., doi: $10.1155 / 2017 / 1353691$ 


\section{Résumé}

Bossoukpe M., Ndiaye O., Diatta O., Diatta S., Audebert A., Couteron P., Leroux L., Diouf A.A., Dendoncker M., Faye E., Taugourdeau S. Un drone pour l'évaluation de la phytomasse ligneuse et herbacée des savanes sahéliennes

La phytomasse des plantes herbacées et ligneuses est la principale source d'alimentation du bétail pastoral dans les savanes sahéliennes. L'évaluation de la matière première disponible joue un rôle clé dans les politiques nationales d'élevage et nécessite généralement de nombreux relevés de mesures de terrain des plantes herbacées et ligneuses. Dans cette étude, nous avons testé la possibilité d'utiliser un drone à bandes spectrales rouge-vert-bleu (RGB) pour évaluer la phytomasse des espèces ligneuses et herbacées. Avec un drone Dji Spark nous avons ainsi cartographié 38 parcelles d'un hectare dans le nord du Sénégal. La phytomasse herbacée a été mesurée au sol. Pour les communautés ligneuses, nous avons évalué la phytomasse foliaire en utilisant des paramètres dendrométriques associés à des équations allométriques. Nous avons effectué des régressions des moindres carrés partiels entre les indices (en trois dimensions et couleurs) obtenus par drone et la phytomasse. Les résultats ont montré un $\mathrm{Q}^{2}$ (résultats de validation croisée pour chaque variable de réponse) de 0,57 pour la phytomasse des ligneux, 0,68 pour la masse sèche des herbacées, et 0,76 pour leur masse fraîche. Cette étude a confirmé la pertinence de l'utilisation d'un drone RGB à faible coût pour l'évaluation de la phytomasse des savanes.

Mots-clés : biomasse aérienne, arbre, graminée, imagerie multispectrale, conduite des herbages, Sahel, Sénégal

\section{Resumen}

Bossoukpe M., Ndiaye O., Diatta O., Diatta S., Audebert A., Couteron P., Leroux L., Diouf A.A., Dendoncker M., Faye E., Taugourdeau S. Un dron para la evaluación de la fitomasa leñosa y herbácea de las sabanas sahelianas

La fitomasa de las plantas herbáceas y leñosas es la principal fuente de alimentación del ganado de pastoreo en las sabanas sahelianas. La evaluación de la materia prima disponible juega un rol clave en las políticas nacionales de cría y requiere generalmente numerosas tomas de medidas de terreno de las plantas herbáceas y leñosas. En este estudio, hemos examinado la posibilidad de utilizar un dron de bandas espectrales rojoverde-azul (RGB) para evaluar la fitomasa de las especies leñosas y herbáceas. Con un dron Dji Spark hemos así cartografiado 38 parcelas de una hectárea en el norte de Senegal. La fitomasa herbácea fue medida en el suelo. Para las comunidades leñosas, hemos evaluado la fitomasa foliar utilizando parámetros dendrométricos asociados a ecuaciones alométricas. Hemos efectuado regresiones de mínimos cuadrados parciales entre los índices (en tres dimensiones y a color) obtenidos mediante dron y la fitomasa. Los resultados mostraron un $\mathrm{Q}^{2}$ (resultados de validación cruzada para cada variable de respuesta) de 0,57 para la fitomasa de las leñosas, 0,68 para la masa seca de las herbáceas y 0,76 para su masa fresca. Este estudio confirmó la pertinencia de la utilización de un dron RGB de bajo costo para la evaluación de la fitomasa de las sabanas.

Palabras clave: biomasa sobre el suelo, árboles, gramineas, imágenes multiespectrales, manejo de praderas, Sahel, Senegal 
